1) 4 UNIYERSITY OF WASHINGTON ${ }_{\text {cor } 1}^{\text {can }}$ DEPARTMENT OF

QCEANOGRAPHY

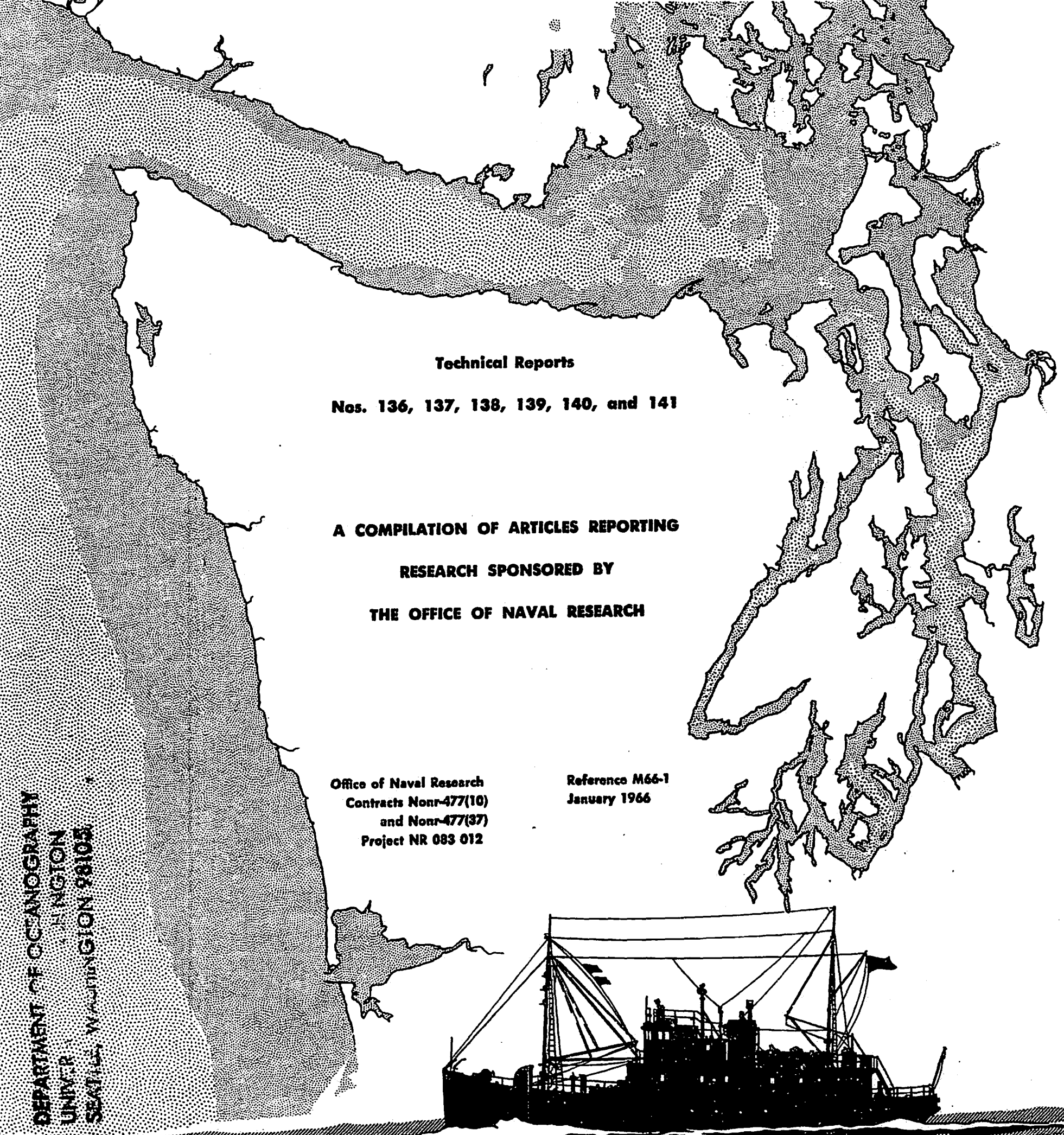


UNIVERSITY OF WASHTIVTON

DEPARTMENT OF OCEANOGRAPHY

Seattle, Washington 98105

Technical Reports

Nos. 136, 137, 138, 139, 140, and 141

A COMPILATION OF ARTICLES REPORTING

RESEARCH SPONSORED BY

THE OFFICE OF NAVAL RESEARCH

Office of Naval Research

Contracts Nonr $-477(10)$ and Nonr-477(37)

Project NR 083012

Reference M66-1 January 1966

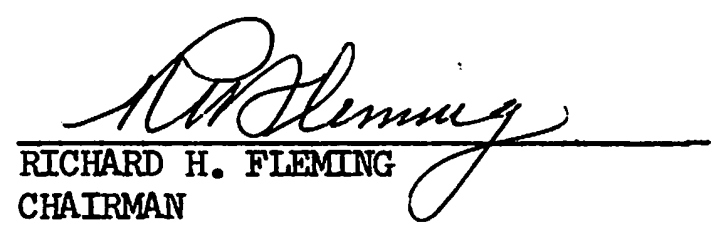

Reproduction in whole or in part is permitted for any purpose of the United States Government 
ARTICLES REPORTING RESEARCH SPONSORED BY THE OFFICE OF NAVAL RESEARCH

Technical Report No. 136

ON THE VERTICAL DISTRIBUTION OF ZOOPIANKTON IN THE SEA, by K. Banse. Pp. 55-125 in Progress in Oceanography, vol. II (Mary Sears, ed.). Pergamon Press, London. 1964.

Technical Report No. 137

SYNONYMS OF PROTODORVIILEA EGENA (EHLERS) (EUNICTIAE, POLYCHAETA), by K. Banse and G. Hartmann-Schrodder. Proceedings of the Biological society of Washington, 77:241-242. 30 December 1964.

Technical Report No. 138

THE INFLUENCE OF VARTABLE DEPTH ON STEADY ZONAL BAROTROPIC FLOW, by Gene H. Porter and Maurice Rattray, Jr. Deutsche Hydrographische Zeitschrift, $17(4): 164-174$. 1964 .

Technical Report No. 139

THE MESOPEIAGIC CARIDEAN SHRTMP NOTOSTOMUS JAPONICUS BATE IN THE NORTHEASTERN PACIFIC, by Belle A. Stevens and Fenner A. Chace, Jr. Crustaceana, 8(pt. 3):277-284. 1965.

Technical Report No. 140

CARBONIFEROUS GIACIAL ROCKS FROM THE WERRIE BASIN, NEW SOUTH WAIES, AUSTRAITA, by John T. Whetten. Geological Society of America Bulletin, 76:43-56. January 1965.

Technical Report No. 141

THE ORIGIN OF MANGANESE NODULES ON THE OCEAN FLOOR, by Enrico Bonatti and Y. Ranmohanroy Nayudu. American Journal of Science, 263:17-39. January 1965. 


\title{
THE MESOPELAGIC CARIDEAN SHRIMP NOTOSTOMUS JAPONICUS BATE IN THE NORTHEASTERN PACIFIC ')
}

\author{
BY \\ BELLE A. STEVENS: ${ }^{2)}$ \\ Department of Oceanography, University of Washington, Seattle, Washington, U.S.A
}

AND

FENNER A. CHACE, JR.

Smithsonian Institution, Washington, D.C., U.S.A.

The relative scarcity of extensive series of Notostomus in study collections and the deficiency of several of the original descriptions have contributed to the confusion that has long characterized the species of this unusual genus of the family Oplophoridae. Among the decapod crustaceans obtained by William Aron during a survey of the mesopelagic fauna of the northeastern Pacific Ocean - a program supported in part by the National Science Foundation (Grant No. G-6168) and in part by the Office of Naval Research (Contract Nonr-477(10)) - are 32 specimens of a shrimp that we have identified as Notostomus japonicus Bate. Inasmuch as this species has been known previously only from the unique, incomplete type specimen, it seems desirable to redescribe the species from the material now available.

The number and arrangement of the lateral carinae on the carapace are so important in the genus Notostomus that an attempt has been made to select names that might be generally acceptable for those carinae. The nomenclature finally adopted (fig. 1) is based in large part on recommendations of L. B. Holthuis after he had reviewed the existing terms for the various carapacic grooves, lines, and ridges in the Natantia.

In the preparation of this redescription, we have done little more than compile the contributions made to the study by others, whose coöperation is hereby gratefully acknowledged. Three members of the staff of the Department of Oceanography at the University of Washington were especially helpful: William Aron, by making the material available, was primarily responsible for initiation of the study; Peter McCrery prepared the careful drawings that illustrate the paper and made notes at sea on the color of living specimens; and Fay I. Linger co-ordinated

1) Contribution No. 321 from the Department of Oceanography, University of Washington, Seattle, Washington. Supported in part by National Science Foundation Grants G.13050 and G-14732.

2) Deceased, September 4, 1960. 
the various contributions to the undertaking and assembled material for the final draft. Isabella Gordon of the British Museum (Natural History) very kindly examined the type specimen of Notostomus japonicus and furnished sketches of its diagnostic characters. Jacques Forest of the Muséum National d'Histoire Naturelle in Paris provided critical observations on the type specimens of Notostomus elegans A. Milne-Edwards and N. gibbosus A. Milne-Edwards. Finally, L. B. Holthuis of the Rijksmuseum van Natuurlijke Historie, Leiden, was most coöperative in numerous ways and offered many suggestions for the improvement of the paper.

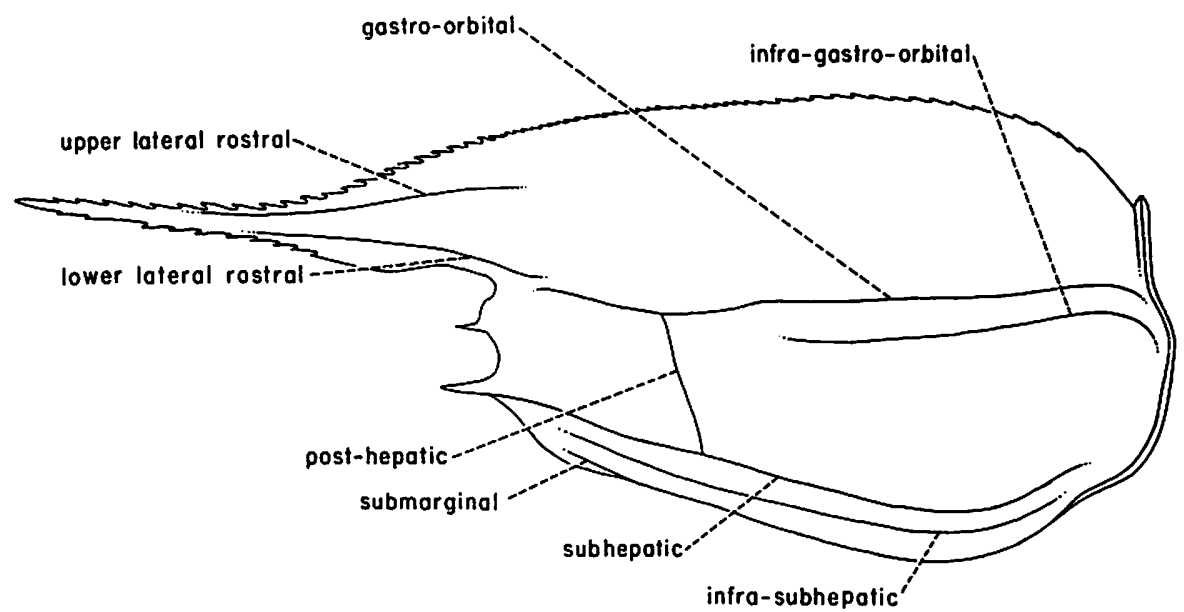

Fig. 1. Idealized Notostomus carapace with full complement of carinae.

Notostomus japonicus Bate, 1888

Notostomus japonicus Bate, 1888: 830, pl. 135 fig. 1.

Material. - All specimens were collected with a 6-foot modified Isaacs-Kidd midwater trawl (Aron, 1962) from the "Brown Bear", research vessel of the Department of Oceanography, University of Washington, from 180 to 850 miles off the west coast of North America, between the latitudes of the southern end of Queen Charlotte Island, British Columbia, and Cape Blanco, Oregon, in midwater depths of 225 to 400 meters. All material is deposited in the U. S. National Museum. The figures in parentheses in the following list are carapace lengths in millimeters, measured from the hind margin of the orbit.

BB-176-124; $49^{\circ} 00^{\prime} \mathrm{N} 144^{\circ} 30^{\prime} \mathrm{W} ; 225 \mathrm{~m}$; September 17, 1957, 0004-0058: 1 female (23.0), 4 juveniles $(20.8,19.8,19.2)$.

BB-199-74; $49^{\circ} 48^{\prime} \mathrm{N} 145^{\circ} 20^{\prime} \mathrm{W} ; 225 \mathrm{~m}$; July 8-9, 1958, 2317-0000: 1 male (31.9), 1 female (30.8),

BB-199-80; $49^{\circ} 30^{\prime} \mathrm{N} 145^{\circ} 53^{\prime} \mathrm{W} ; 225 \mathrm{~m}$; July 9-10, 1958, 2342-0039: 2 males $(28.2,25.9)$.

BB.199-93; $47^{\circ} 16^{\prime} \mathrm{N} 146^{\circ} 25^{\prime} \mathrm{W}$; $225 \mathrm{~m}$; July 11, 1958, 0314-0412: 1 female (29.0).

BB-199-112; $42^{\circ} 58^{\prime} \mathrm{N} 145^{\circ} 37^{\prime} \mathrm{W} ; 250-300 \mathrm{~m}$; July 13-14, 1958, 2308-0013: 1 female (24.8).

BB-199-290; $45^{\circ} 49^{\prime} \mathrm{N} 139^{\circ} 40^{\prime} \mathrm{W} ; 400 \mathrm{~m}$; August 13, 1958, 0245-0402: 1 female (20.2).

BB-199-296; $47^{\circ} 47^{\prime} \mathrm{N} 142^{\circ} 06^{\prime} \mathrm{W} ; 400 \mathrm{~m}$; August 14, 1958, 0250.0407: 1 female (26.2),

2 juveniles $(17.9,14.0)$.

BB-199-297; $48^{\circ} 04^{\prime} \mathrm{N} 142^{\circ} 35^{\prime} \mathrm{W} ; 225 \mathrm{~m}$; August 14-15, 1958, 2345-0044: I young male (22.2), 1 juvenile (14.7). 
BB 202-15; $49^{\circ} 50^{\prime} \mathrm{N} 133^{\circ} 20^{\prime} \mathrm{W} ; 400 \mathrm{~m}$; September 24, 1958, 0153-0310: 1 male (31.7).

BB-202-26; $49^{\circ} 59^{\prime} \mathrm{N} 138^{\circ} 17^{\prime} \mathrm{W}$; $400 \mathrm{~m}$; September 26, 1958, 0318.0440: 1 male (29.5), 1 female (33.0).

BB-202-32; $48^{\circ} 59^{\prime} \mathrm{N} 140^{\circ} 09^{\prime} \mathrm{W}$; $400 \mathrm{~m}$; September 27, 1958, 0335-0451: 1 male (28.3),

2 females (29.3 with bopyrid branchial parasite, 22.0).

BB-202-53; $47^{\circ} 58^{\prime} \mathrm{N} 132^{\circ} 15^{\prime} \mathrm{W}$; $400 \mathrm{~m}$; September 29, 1958, 2129-2242: 1 male (27.3):

1 female (20.3).

BB-202-62; $47^{\circ} 58^{\prime} \mathrm{N} 131^{\circ} 35^{\prime} \mathrm{W} ; 400 \mathrm{~m}$; September 30, 1958, 0425-0539: 1 juvenile (13.4). BB-235-17; $52^{\circ} 08^{\prime} \mathrm{N} 138^{\circ} 33^{\prime} \mathrm{W}$; $400 \mathrm{~m}$; July 19, 1959, 2205-2317: 1 male (33.1).

BB-254-23; $44^{\circ} 26^{\prime} \mathrm{N} 131^{\circ} 14^{\prime} \mathrm{W} ; 400 \mathrm{~m}$; March 20, 1960, 2227-2348: 1 young male (23.2).

BB-254-24; $44^{\circ} 29^{\prime} \mathrm{N} 131^{\circ} 14^{\prime} \mathrm{W}$; $225 \mathrm{~m}$; March 20-21, 1960, 2350-0042: 1 juvenile (9.3).

BB-254-30; $46^{\circ} 14^{\prime} \mathrm{N} 130^{\circ} 49^{\prime} \mathrm{W} ; 400 \mathrm{~m}$; March 21, 1960, 2233-2350: 1 young male (19.3), 1 juvenile $(14.0)$.

BB-254-42; $47^{\circ} 14^{\prime} \mathrm{N} 129^{\circ} 00^{\prime} \mathrm{W} ; 400 \mathrm{~m}$; March 23, 1960, 0252-0400: 1 female (21.3).

Description. - Carapace (fig. 2) moderately inflated. Dorsal margin sharply carinate, finely and closely denticulate behind level of orbital margin, and rather feebly arched above level of rostrum, often nearly horizontal in posterior half.

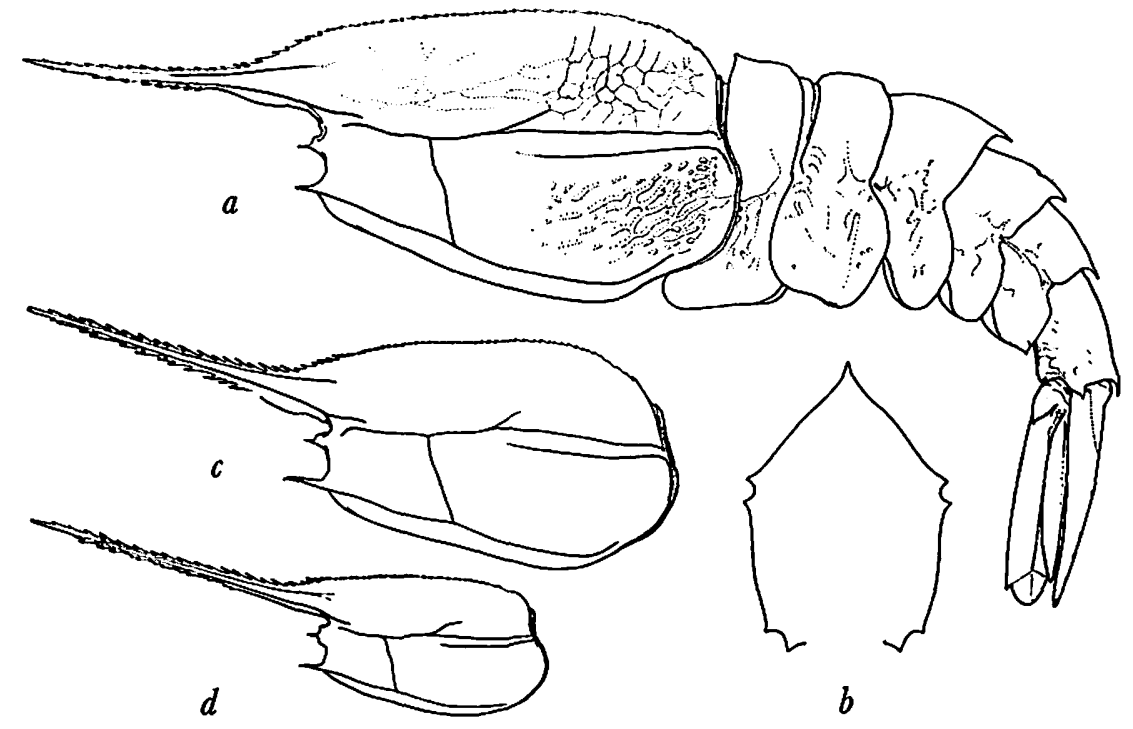

Fig. 2. Notostomus japonicus Bate. a, carapace and abdomen of female with carapace length of $26.2 \mathrm{~mm}$ from "Brown Bear" Sta. 199.296; b, transverse section of carapace of same specimen at point of maximum height; $c$, carapace of juvenile with carapace length of $21.3 \mathrm{~mm}$ from "Brown Bear" Sta. 254-42; d, carapace of juvenile with carapace length of $14.0 \mathrm{~mm}$ from "Brown Bear" Sta. 199-296.

Three prominent longitudinal carinae - gastro-orbital, subhepatic, and submarginal - extending for nearly entire length of lateral surface. Gastro-orbital carina not continuous with lower lateral rostral. Infra-gastro-orbital carina extending approximately two-thirds of distance from posterior margin to prominent posthepatic carina. A characteristic, short, sometimes sinuous carina extending obliquely upward and backward from gastro-orbital carina at a point just anterior to end of inf ra-gastro-orbital carina. Suborbital angle usually bluntly rectangular, occasionally 


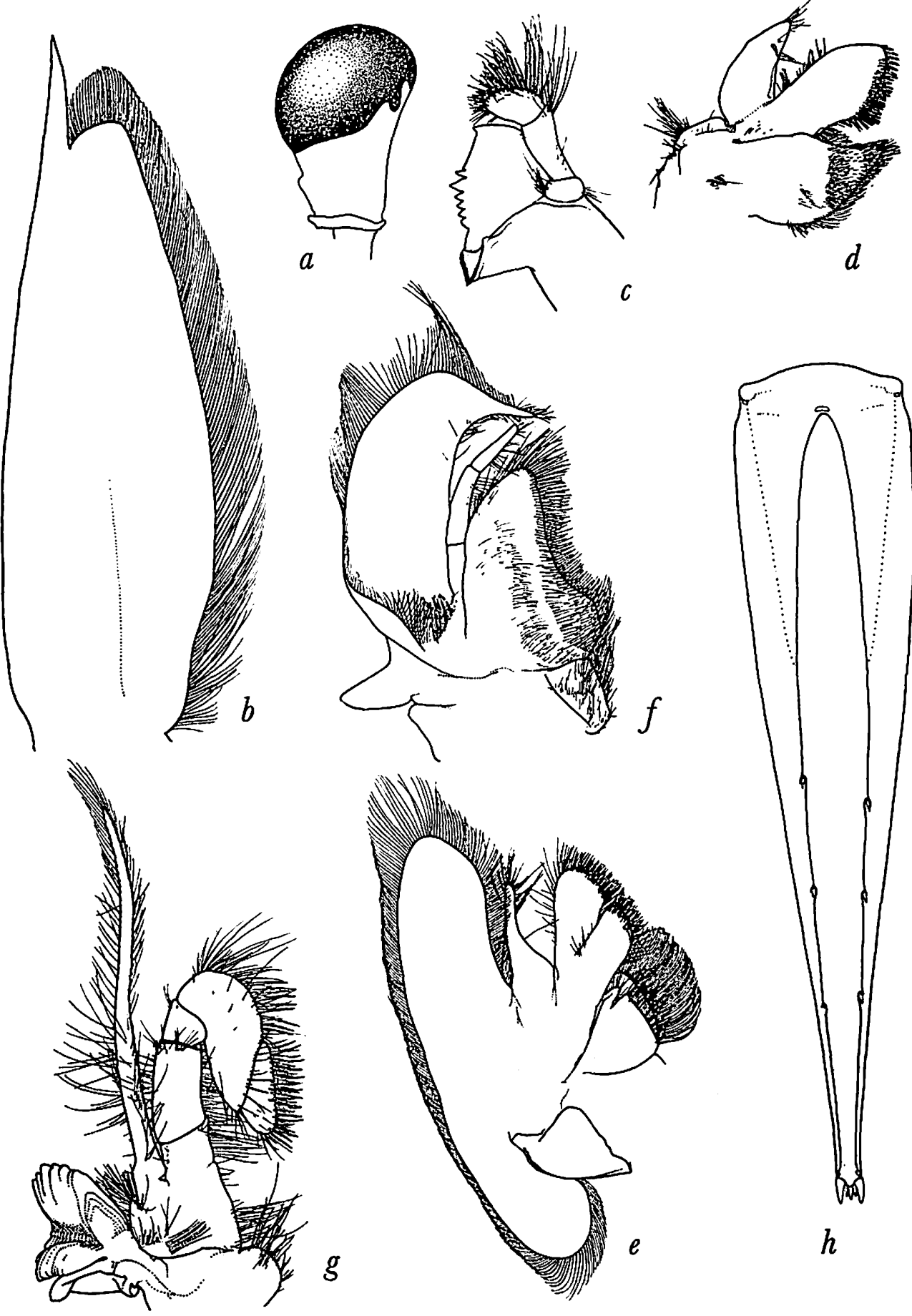

Fig. 3. Notostomus japonicus Bate, female with carapace length of $29.3 \mathrm{~mm}$ from "Brown Bear" Sta. 202.32. a, right eye in dorsal view; $b$, right antennal scale in ventral view; $c$, mandible; $d$, first maxilla; e, second maxilla; f, first maxilliped; $g$, second maxilliped; $h$, telson. 
either subacute or somewhat obtuse. Antennal spine distinct. Branchiostegal spine very long and prominent. Rostrum from slightly longer than, to one and twothirds as long as, carapace in juvenile specimens with carapace lengths of less than $20 \mathrm{~mm}$ (fig. 2d); subequal to, or slightly shorter than, carapace in young adults with carapace lengths of 20 to $25 \mathrm{~mm}$ (fig. 2c); scarcely more than two-thirds as long as carapace in larger specimens with carapace lengths of 25 to $33 \mathrm{~mm}$ (fig. 2a). Upper lateral rostral carina slightly nearer to dorsal margin than to lower lateral rostral carina. Rostrum armed with 20 to 33 dorsal and 10 to 18 ventral spines; spines of rostral series at least twice as long as denticles on dorsal margin of carapace.

Eyes (fig. 3a) wider than eyestalks. Distinct papilla on inner surface of stalk. Outer spine of basal antennular segment sharp, with expanded, sinuous outer margin. Stylocerite with long, slender terminal spine rarely reaching as far as outer spine of basal segment. Antennal scale (fig. 3b) with long, stout outer spine reaching far beyond end of blade. Mouth parts (fig. 3c-g) typical for genus. Third maxillipeds (fig. 4a) reaching to or slightly beyond outer spine of antennal scale. First pereiopods (figs. $4 b, c, h$ ) reaching about halfway from end of antennular peduncle to end of antennal scale. Second pereiopods (figs. 4d, e) reaching slightly beyond first pereiopods but not as far as end of antennal scale. Third pereiopods reaching beyond antennal scale by length of dactyl and distal one-fifth to one-half of propodus. Fourth pereiopods reaching beyond antennal scale by length of dactyl and sometimes by as much as one-fourth of propodus. Fifth pereiopods falling slightly short of, or slightly overreaching, end of antennal scale. First and second pleopods as figured (figs. 4f, $g$, i, $j$, see Size).

Variation. - Except for the relative height of the carapace and the length and angle of the rostrum (fig. 2), the variable characters noted (number of rostral spines, configuration of posterior margin of fifth abdominal pleuron, number of dorsal spines on telson, and relative lengths of thoracic appendages) show no correlation with the age or sex of the individual specimens.

Color. - General color in life, red with all carinae darker than rest of integument.

Size. - The appendix masculina is a barely visible bud in the two smallest males, with carapace lengths of 19.3 and $22.2 \mathrm{~mm}$. It is one-half as long as the appendix interna in a male with a carapace length of $23.2 \mathrm{~mm}$, and less than onethird as long in a specimen having a carapace length of $25.9 \mathrm{~mm}$. At carapace lengths of $27.3,28.2$, and $28.3 \mathrm{~mm}$, it is subequal to the appendix interna, but it is proportionately slightly shorter in a specimen with a carapace length of 29.5 $\mathrm{mm}$. Only in the two largest males, which have carapace lengths of 31.9 and $33.1 \mathrm{~mm}$, is the appendix masculina longer (by about one-fourth) than the appendix interna. Inasmuch as the male holotype of $N$. japonicus is considerably larger (carapace length $42 \mathrm{~mm}$ ) than any of the specimens seen by us, and as no ovigerous specimens are represented, it is possible that none of the specimens in the present collection are fully mature. 
Distribution. - The only specimen of $N$. japonicus previously recorded was trawled by the "Challenger" south of Honshu Island, Japan, in a total depth of

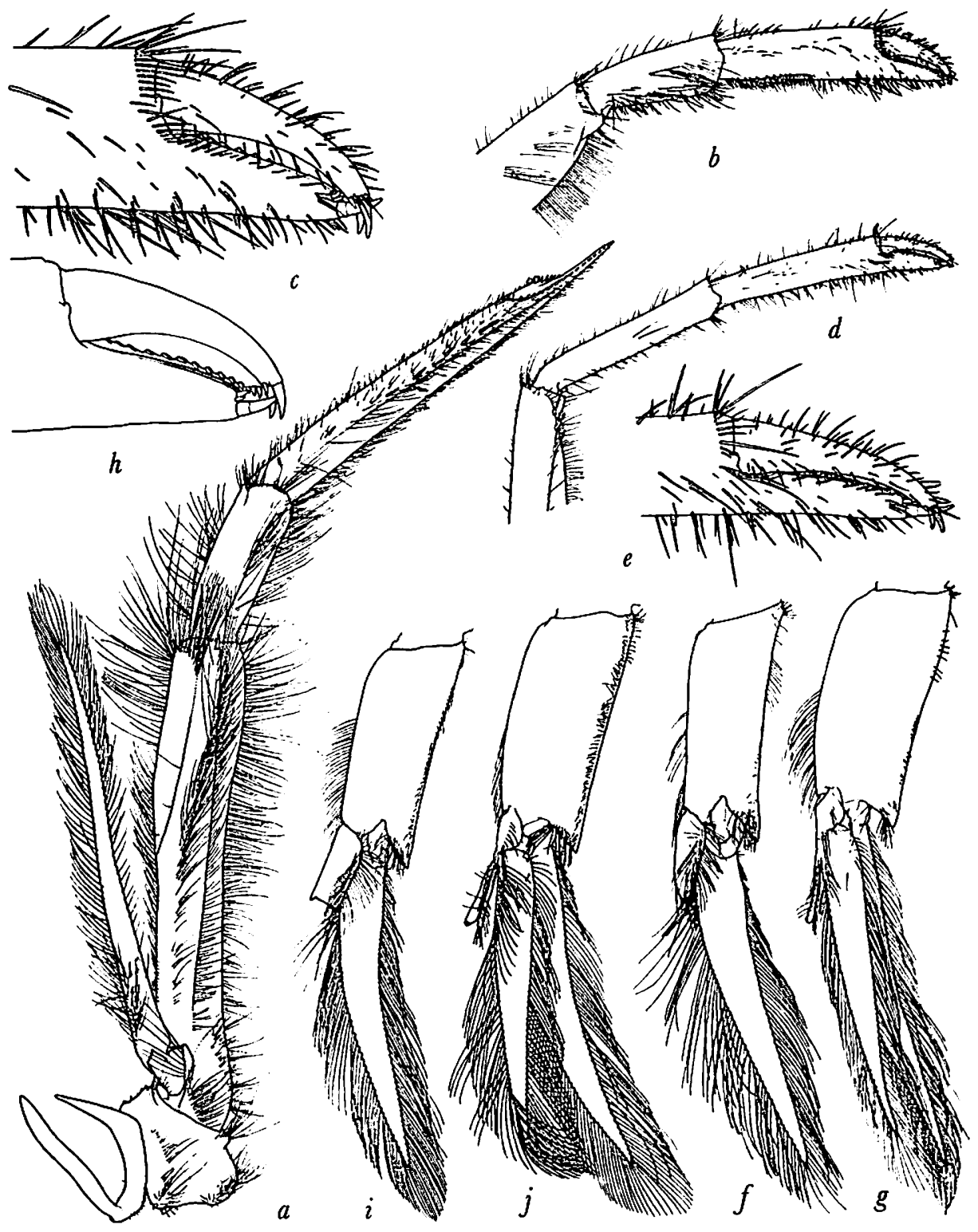

Fig. 4. Notostomus japonicus Bate. a, third maxilliped of female with carapace length of $29.3 \mathrm{~mm}$ from "Brown Bear" Sta. 202-32; b, distal segments of first pereiopod of same specimen; $c$, fingers of same; d, distal segments of second pereiopod of same specimen; e, fingers of same; $f$, first pleopod of same specimen; $g$, second pleopod of same specimen; h, denuded fingers of first pereiopod of female with carapace length of $29.0 \mathrm{~mm}$ from "Brown Bear" Sta 199-93; i, first pleopod of male with carapace length of $28.3 \mathrm{~mm}$ from "Brown Bear" Sta. 202-32; $j$, second pleopod of same specimen. 
565 fathoms. The vertical distribution of the material collected by the "Brown Bear" suggests diurnal migration. All but one of the 14 specimens found between 225 and 300 meters were taken within one hour of midnight, and the 18 specimens from 400 meters were taken either between 9:29 and 11:50 p. m. or between $1: 53$ and 5:39 a. $\mathrm{m}$.

Remarks. - N. japonicus is apparently distinguished from other species of the genus by the following combination of characters: Dorsal margin of carapace not strongly arched, four longitudinal carinae on posterior half of lateral surface of carapace, upper lateral rostral carina present, gastro-orbital carina not continuous with lower lateral rostral carina, and, especially, a short carina directed obliquely upward and backward from middle of gastro-orbital carina.

Although Bate (1888) stated in his description of the species that "a small ridge runs from the upper margin of the rostrum and dies out above the frontoorbital region", there is no indication of an upper lateral rostral carina in his figure. We are indebted to Isabella Gordon for examining the holotype of $N$. japonicus and verifying the existence, not only of that carina, but also of the short, oblique carina that branches from the middle of the gastro-orbital; the latter was not mentioned by Bate nor has it been recorded, to our knowledge, for any other species of Notostomus. The only remaining discrepancy between Bate's description and the material described above concerns the length of the telson relative to the uropods; it is not unlikely that Bate's statement that the telson "is shorter than the inner lateral plate of the rhipidura" was descriptive of the tail fan in a flexed position.

Because our material was referable to $N$. elegans A. Milne-Edwards, 1881, in the key to the species of the genus in Chace (1936), we asked Dr. Jacques Forest to re-examine the type specimen of that species in the Muséum National d'Histoire Naturelle in Paris. He very kindly reported that there is an upper lateral rostral carina in that specimen, but that it terminates at the level of the orbital margin, rather than more posteriorly as indicated in the figure in A. Milne-Edwards (1883). He also determined that the lower lateral rostral and the gastro-orbital carinae are not continuous, in contradistinction to the condition suggested by MilneEdwards' figure. Finally, Dr. Forest informed us that there are five lateral longitudinal carinae on the posterior half of the carapace in $N$. elegans. The latter character removes the species from consideration as far as the present collection is concerned, but it suggests the need to review the identity of such species as N. longirostris Bate, 1888; N. westergreni Faxon, 1893; and N. atlanticus Lenz, 1914.

Our observations on the present series of specimens may assist in evaluating the status of some of the other species of Notostomus that are known from few specimens of different sizes. This study tends to substantiate the belief expressed by Kemp (1913: 66) that the carination of the carapace in this genus is constant during late post-larval growth. 


\section{ZUSAMMENFASSUNG}

Notostomus japonicus wird neubeschrieben auf Grund von 32 Exemplaren, die in 225 bis $400 \mathrm{~m}$ Tiefe westlich von British Columbia, Washington, und Oregon entnommen wurden. Bei Individuen mit Carapaxlängen zwischen 9,3 bis 33,1 mm sind die diagnostischen Merkmale in beiden Geschlechtern in allen Altersklassen gleich und zeigen keine signifikante Variation.

\section{LITERATURE CITED}

Aron, Willinm, 1962. Some aspects of sampling the macroplankton. Rapp. Proc..Verb. Cons. internat. Explor. Mer, 153 (5): 29-38, text-figs. 1-4.

BATE, C. SPENCE, 1888. Report on the Crustacea Macrura collected by H. M. S. Challenger during the years 1873-76. Rep. Voy. Challenger, (Zool.) 24: i-xc, 1-942, text-figs. 1-76, pls. 1-150.

CHACE, FenNer A., Jr., 1936. Revision of the bathypelagic prawns of the family Acanthephyridae, with notes on a new family, Gomphonotidae. J. Washington Acad. Sci., 26: 24-31.

FAXON, Walter, 1893. Preliminary descriptions of new species of Crustacea. Reports on the dredg. ing operations off the west coast of Central America to the Galapagos, to the west coast of Mexico, and in the Gulf of California, in charge of Alexander Agassiz, carried on by the U. S. Fish Commission Steamer "Albatross", during 1891. VI. Bull. Mus. Comp. Zoöl., Harvard, 24: 149-220.

Kemp, Stanley, 1913. Pelagic Crustacea Decapoda of the Percy Sladen Expedition in H.M.S. "Sealark". The Percy Sladen Trust Expedition to the Indian Ocean in 1905, under the leadership of Mr. J. Stanley Gardiner. Trans. Linn. Soc. London, Zool., (2) 16: 53-68, pl. 7.

LeNZ, H. \& K. STRUNCK, 1914. Die Dekapoden der Deutschen Südpolar-Expedition 1901-1903. I. Brachyuren und Macruren mit Ausschluss der Sergestiden. Deutsche Südpolar-Exped., 15: 257.345, text-figs. 1.5 , pls. 12-22.

Milne-Edwards, A., 1881. Description de quelques Crustacés Macroures provenant des grandes profondeurs de la mer des Antilles. Ann. Sci. nat., Zool., (6) 11 (4): 1-16.

- 1883. Recueil de figures de Crustacés nouveaux ou peu connus: 1-3, pls. 1-44. 